\title{
Investigation on Stress Profile of Double Bolted Cold- Formed Steel Channel Beam
}

\author{
Fadhluhartini Muftah, Mohd Syahrul Hisyam Mohd Sani, Mohd Fakri Muda, and Tan Cher Siang
}

\begin{abstract}
Cold-formed steel sections are popular nowadays with a lot of advantages such as lightweight, thinner, less maintenance and ease to transport. With a lot of advantages, the study used two channels and bolted side by side to produce beam. The beam is established with symmetrical section and their strength investigated due to bending. The arrangement of the bolt is important to determine the relationship of the strength. In the study, there are 3 types arrangement of bolt spacing. The high stress illustrated in this study is recorded with bolt spacing $225 \mathrm{~mm}$ and end bolt spacing $230 \mathrm{~mm}$. The stress showed lowest value when compared with hollow, solid section and reinforced concrete beam.
\end{abstract}

Index Term-Stress profile, double bolted cold-formed steel channel, beam

\section{INTRODUCTION}

Cold-formed steel sections are modern building products that are widely used in roof systems of large structures such as industrial, commercial buildings and warehouses throughout the world. Cold formed steel sections are favorable lighter construction material due to thinner in the thickness. Cold-formed steel sections serve as intermediate members between the main structural frame and the corrugated roof or wall sheeting in light gauge steel construction. A variety of shapes and forms of cold-formed steel are available nowadays and generally cross-section of the members is of zed, channel or sigmas which are undergoes both bending and twists from the beginning of loading. These types of cross-sections are inherently sensitive to local, distorsional, and lateral-torsional buckling. The cold-formed steel is thinner and lightweight than hot-rolled steel.

The cold-formed steel structure usually used as purlin or as beam on roof truss system. Most researchers believe that metal or roofing sheeting connected on the top of purlin side restraint the lateral movement of whole purlin. However, due to unsymmetrical section of the purlin, the restraint provided by the metal sheeting is not enough to stop lateral and torsion movement at lower side. Due to this movement, the purlin may fail prematurely in lateral torsional buckling without achieving its bending capacity. Therefore the used of symmetrical section of purlin or beam been introduced hence reduce severe lateral and torsion movement. Varieties of section with symmetrical section

Manuscript received February 9, 2013; revised May 8, 2013.

Fadhluhartini Muftah, Mohd Syahrul Hisyam Mohd Sani, and Mohd Fakri Muda are with Faculty of Civil Engineering, Universiti Teknologi Mara, Malaysia (email: fadhlu@pahang.uitm.edu.my, msyahru1210@pahang.uitm.edu.my, fakri@pahang.uitm.edu.my).

Tan Cher Siang is with Faculty of Civil Engineering, Universiti Teknologi Malaysia (email: tcsiang@utm.my). has been established and the bolt and nut also recommended to connect the two section or more.

Generally, the grades of carbon steel and high strength low alloy steel used for cold-formed steel products are characterized by two main properties: the yield point and the tensile strength. Other important properties are ductility, hardness and weld ability. The yield point of the steels commonly used for cold-forming ranges from 33 to $55 \mathrm{ksi}$ ( 230 to $380 \mathrm{MPa}$ ), and may be higher. Tensile strength and ductility are important because of the way they relate to formability, and because of the local deformation demands of bolted and other types of connection. In members that include bolted connection or that, because of special design, may be subject to high stress concentrations, the tensile strength often must be taken into account. The ratio of tensile strength to yield strength for cold-formed steels commonly ranges from 1.2 to 1.8 . However, steels with a lower ratio can be used for specific and definite applications.

Past research into the performance of double section cold-formed steel members as a beam structure is limited. Therefore a research project was undertaken to investigate the structural behavior of double section cold-formed Cchannel beams subject to bending effects. The research focused on flexural test. The test is used to determine the flexure or bending properties of a material. Sometimes referred to as a transverse beam test, it involves placing a sample between two knife-edge points and initiating a load at the midpoint of the sample. Maximum stress and strain are calculated on the incremental load applied. Results are shown in a graphical format with tabular results including the flexural strength (for fractured samples) and the yield strength (samples that did not fracture).

Theory of bending stress is a form of stress seen when loads are applied perpendicularly to an object or sample tested, forcing it to deflect under the load. The degree of bending an object will tolerate before it becomes permanently deformed varies, depending on the construction materials, size, point load and other variables. During bending, several different physical phenomena are occurring. As an object bends, one side becomes compressed because it is being partially folded under the weight of the load while the other side becomes stretched as the tension occur. Repeated sessions of bending stress, followed by a reduction of the load can result in cracks, creases, and other problems caused by the stretching and compression. This can weaken the object and make it more at risk of permanent deformation or breakage in the future, even under the same load.

However in this study, the aim is to further investigate other lateral restraint method in order to provide a wider choice of bridging. The good lateral restraint method will be achieved by higher stiffness of section use with 
application of economical arrangement.

Many researchers have studied about the cold-formed steel beam with different shape and model [1]-[4]. Reference [5] is reported of the study on cold-formed steel channels subjected to combined bending and web crippling by using modeling and experiment. The plain and lipped channel of thin-walled cold-formed (TWCF) steel section are tested in compression and bending [6]. The comparison study of channel beam with doubled box flanges and channel beam with lipped flanges are examined due to pure bending [7]. Reference [8] described the behavior effects that influenced the plastic bending behavior and section moment capacity of the cold-formed LiteSteel beam (LSB) sections.

\section{MethodOLOGY}

\section{A. Preparation of the Sample}

The channel section of cold-formed steel are selected and bought from the steel industry supplier. The dimension of the section is $50 \mathrm{~mm}$ breadth of web and $100 \mathrm{~mm}$ of height that illustrated in Fig. 1.

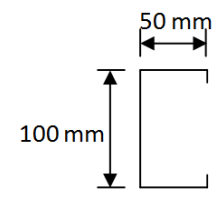

Fig. 1. The dimension of the channel section

Then, the channel is cleaned and cleared from the substances and impurities that can affect the reading. The two channels are put in different way and bolted each other to become one section as shown in Fig. 2. The three bolts with the body size of $6.94 \mathrm{~mm}$ and thread size of $6.85 \mathrm{~mm}$ are used with varies bolted location that are shown in Fig. 2 and Table I.

TABLE I: PROPERTIES OF SAMPLE BEAM

\begin{tabular}{|c|c|c|c|}
\hline Sample & Beam A & Beam B & Beam C \\
\hline Depth, D (mm) & 100 & 100 & 100 \\
\hline Width, B (mm) & 100 & 100 & 100 \\
\hline Thickness , t (mm) & 1.5 & 1.5 & 1.5 \\
\hline Length between support (mm) & 750 & 750 & 750 \\
\hline Bolt spacing, S (mm) & 345 & 300 & 225 \\
\hline End spacing, e (mm) & 105 & 150 & 230 \\
\hline
\end{tabular}

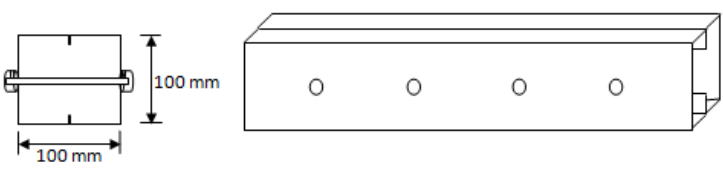

Fig. 2. The new section dimension and the location of bolt on beam

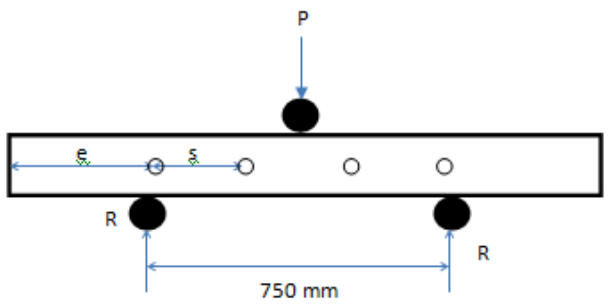

Fig. 3. The schematic diagram of three bending testing

\section{B. Experimental and Data Collection}

The double bolted channel cold-formed steel section are been tested by using Auto 3000kN Compression Machine. The section is placed in the apparatus using 3 pinned positions as shown in Fig. 3. After preparing and safely placed the section, the machine is started. The results from the machine are taken.

\section{RESULTS AND DISCUSSION}

\section{A. Experimental Stress in Beam}

TABLE II: The StREsS Result FOR THE ThreE TyPes OF SAMPle

\begin{tabular}{|c|c|c|c|}
\hline Sample & Beam A & Beam B & Beam C \\
\hline Pace rate & 0.05 & 0.05 & 0.05 \\
\hline Maximum Load, $(\mathrm{kN})$ & 19.53 & 20.16 & 28.92 \\
\hline Stress (N/mm $\left.{ }^{2}\right)$ & 2.930 & 3.024 & 4.339 \\
\hline
\end{tabular}

The experiment yields the stresses in beam A, B and C at $2.93 \mathrm{~N} / \mathrm{mm}^{2}, 3.024 \mathrm{~N} / \mathrm{mm}^{2}$, and $4.339 \mathrm{~N} / \mathrm{mm}^{2}$ respectively as shown in Table II. The experiment of three pinned banding on beam shows that as the spacing of bolt is closer, the load carrying capacity of constant cross section is higher as shown in the Fig. 4. The load for $225 \mathrm{~mm}$ spacing recorded as the highest load at $28.92 \mathrm{kN}$. It is concluded that the spacing of the bolt is significant to carrying higher load capacity of the double bolted cold formed beam. The decreasing in spacing $45 \mathrm{~mm}$ lead to $0.63 \mathrm{kN}$ load increment, $1 \mathrm{~mm}$ spacing increase load up to $0.014 \mathrm{kN}$. Meanwhile $75 \mathrm{~mm}$ spacing increment lead to $8.76 \mathrm{kN}$, and $1 \mathrm{~mm}$ spacing may increase up to $0.11 \mathrm{kN}$. The results show in non-linear relationship of load increment to the spacing of bolt. It was fit to a binomial relationship. The current results concluded that, the spacing above $300 \mathrm{~mm}$ is insignificant to increase the load carrying capacity of the double bolted cold formed steel beam. Therefore the estimation of spacing to achieve maximum effective load can be done by binomial relationship of the following equation:

$$
\mathrm{P}=4.1 \mathrm{~s}^{2}-11.6 \mathrm{~s}+27
$$

Given, P - Maximum load \& S - Spacing of bolt

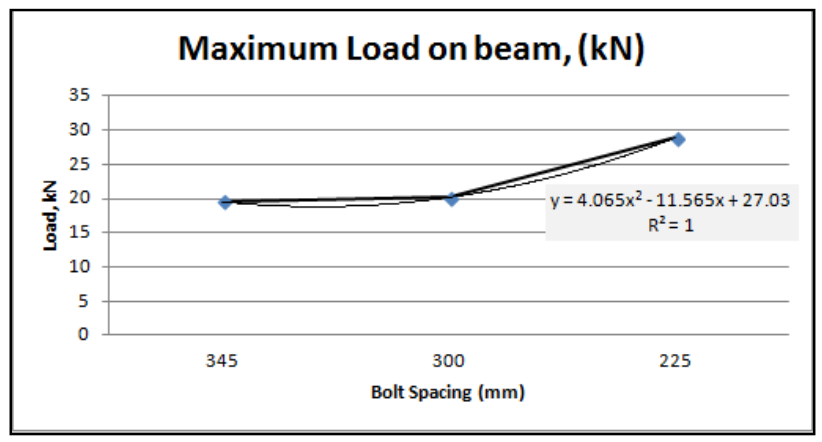

Fig. 4. The graph of load versus bolt spacing

\section{B. $\quad$ Theoretical Stress in Beam}

Further analysis is required to check the cost effective of using bolt in the study. The results of load from sample Beam A is using to identify the stresses at ame load level of $19.53 \mathrm{kN}$. The analysis is done by Elastic Bending Theory. The calculation results by using the Elastic Bending Theory 
as shown in Table. The checking is done by comparing the double bolted cold formed steel beam to the Hollow section without bolt along the length of beam and solid square section along the beam at same size of $100 \mathrm{~mm} \times 100 \mathrm{~mm}$. Theoretically, beams are not only subjected to bending stress but also to shear stress. The calculation shows that the section of $100 \mathrm{~mm} \times 100 \mathrm{~mm}$ in the test set-up is purely in bending because the shear stress is lower at $37.18 \mathrm{~N} / \mathrm{mm}^{2}$ and $1.47 \mathrm{~N} / \mathrm{mm}^{2}$ for hollow and solid section. In order to compare the results of the experiment, both bending and total stresses should be used.

\section{Hollow Cross Section \& Solid Beam Cross Section}

From the Table III is showed that the double bolted cold formed steel beam recorder as the lowest stress induce in the beam while hollow section is the highest in stress. It shows that the used of bolted in beam is really significant to reduce stress for hollow section as referred to Table IV. Besides that, it is very cost effective to used hollow section rather than solid section and also results in lower stress.

TABLE III: THE DATA OF Hollow SECTION AND SOlID SQUARE SECTION

\begin{tabular}{|c|c|c|}
\hline Beam & $\begin{array}{c}\text { Hollow } \\
\text { section }\end{array}$ & $\begin{array}{c}\text { Solid } \\
\text { square }\end{array}$ \\
\hline Maximum Load $(\mathrm{kN})$ & 19.53 & 19.53 \\
\hline Second moment area about $\mathrm{x}-\mathrm{x}$, Ixx $\left(\mathrm{mm}^{4}\right)$ & $955.89 \times 10^{3}$ & $8.33 \times 10^{6}$ \\
\hline $\begin{array}{c}\text { Second moment area about } \mathrm{y}-\mathrm{y}, \text { Iyy } \\
\left(\mathrm{mm}^{4}\right)\end{array}$ & $955.89 \times 10^{3}$ & $8.33 \times 10^{6}$ \\
\hline $\begin{array}{c}\text { Theoretical Elastic shear stress }, \tau \\
\left(\mathrm{N} / \mathrm{mm}^{2}\right)\end{array}$ & 37.18 & 1.47 \\
\hline $\begin{array}{c}\text { Theoretical Elastic shear stress }, \sigma \\
\left(\mathrm{N} / \mathrm{mm}^{2}\right)\end{array}$ & 191.54 & 21.98 \\
\hline $\begin{array}{c}\text { Total Theoretical Elastic stress },(\tau+\sigma) \\
\left(\mathrm{N} / \mathrm{mm}^{2}\right)\end{array}$ & 228.73 & 23.45 \\
\hline
\end{tabular}

TABLE IV: COMPARISON DATA BETWEEN THREE SECTIONS

\begin{tabular}{|c|c|}
\hline Experimental Stress & $2.93 \mathrm{~N} / \mathrm{mm}^{2}$ \\
\hline Theoretical Elastic stress for hollow section without bolt & $228.73 \mathrm{~N} / \mathrm{mm}^{2}$ \\
\hline Total Theoretical Elastic stress for solid square beam & $23.45 \mathrm{~N} / \mathrm{mm}^{2}$ \\
\hline
\end{tabular}

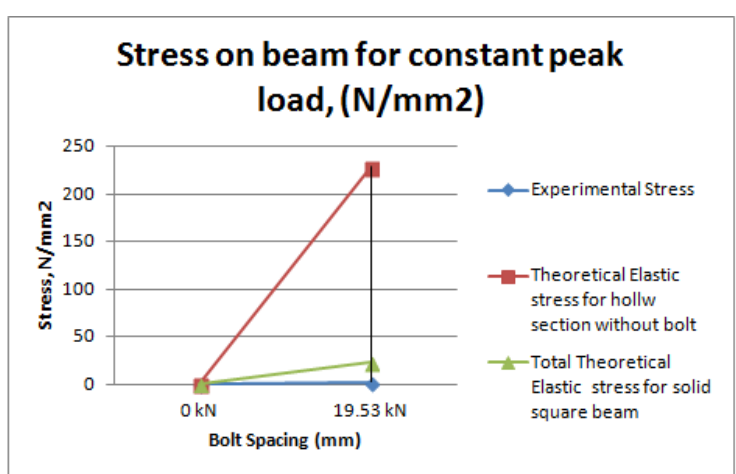

Fig. 5. The graph of stress versus bolt spacing

Fig. 5 shows the stresses in beam .Therefore the double bolted cold formed steel beam is considered to be stiffer and may carrying a higher load level.

D. Stress and Deflection of Reinforced Concrete Beam

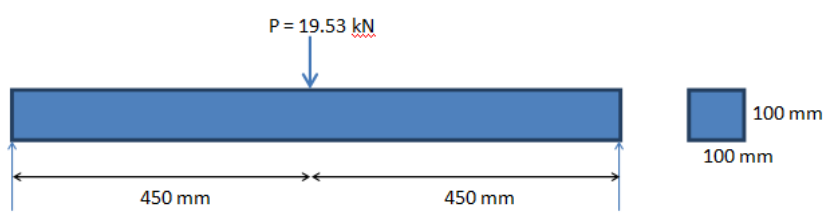

Given; $\mathrm{P}=19.53 \mathrm{kN}, \mathrm{E}=30000 \mathrm{~N} / \mathrm{mm}^{2}, \mathrm{~L}=900 \mathrm{~mm}, \mathrm{Y}=$ $50 \mathrm{~mm}, \mathrm{I}=8.33 \times 10^{6} \mathrm{~mm}^{4}$

Reaction at support $=9.765 \mathrm{kN}$

$$
\begin{aligned}
& \text { Max Stress }=y F L / 4 I=(50)(19530)(900) /\left(4 \times 8.33 \times 10^{6}\right) \\
& =26.37 \mathrm{~N} / \mathrm{mm}^{2}
\end{aligned}
$$

Max Deflection $=\mathrm{FL}^{3} / 48 \mathrm{EI}=(19530)\left(900^{3}\right) / 48(30000)$ $\left(8.33 \times 10^{6}\right)=1.19 \mathrm{~mm}$

\section{CONCLUSION}

Load and spacing of bolt of double bolted cold formed steel beam relation is a binomial relationship. The relationship is $\mathrm{P}=4.1 \mathrm{~s}^{2}-11.6 \mathrm{~s}+27$. Hence, the spacing above $300 \mathrm{~mm}$ is insignificant to increase the load carrying capacity of the double bolted cold formed steel beam.

Double bolted cold formed steel beam recorder as the lowest stress induces in the beam at $2.93 \mathrm{~N} / \mathrm{mm}^{2}$ followed by solid beam at $23.45 \mathrm{~N} / \mathrm{mm}^{2}$ and hollow section is the highest in stress at $228.73 \mathrm{~N} / \mathrm{mm}^{2}$ at the same load level of $19.53 \mathrm{kN}$. It shows that the used of bolted in beam is really significant to reduce stress for hollow section. Besides that, it is very cost effective to used hollow section rather than solid section and also results in lower stress.

\section{REFERENCE}

[1] H. Wang \& Y. Zhang, "Experimental and numerical investigation on cold-formed steel C-section flexural members," Journal of Construction Steel Research, vol. 65, pp. 1225 - 1235, 2009.

[2] M. D’Aniello, R. Landolfo, V. Piluso, and G. Rizzano, "Ultimate bahaviour of steel beams under non-uniform bending," Journal of Constructional Steel Research, vol. 78, pp. 144 - 158, 2012.

[3] L. Y. Huei, L. Y. Ling, and T. C. Siang, "Experimental investigation on cold-formed steel beams under pure bending," Journal Teknologi (Sciences \& Engineering), vol. 58, pp. 13 - 20, 2012.

[4] K. Magnucki, M. Rodak, and J. Lewinski, "Optimization of monoand anti-symmetrical i-sections of cold-formed thin-walled beams," Thin-walled Structures, vol. 44, pp. 832-836, 2006.

[5] W-X. Ren, S-E Fang, and B. Young, "Analysis and design of coldformed steel channels subjected to combined bending and web crippling," Thin-walled Structure, vol. 44, pp. 314-320, 2006.

[6] V. Ungureanu, M. Kotelko, R. J. Mania, and D. Dubina, "Plastic mechanisms database for thin-walled cold-formed steel members in compressive and bending," Thin-Walled Structures, vol. 48, pp. 818826, 2010.

[7] E. Magnucka-Blandzi, "Effective shaping of cold-formed thin-walled channel beams with doubled-box flanges in pure bending," Thinwalled Structures, vol. 49, pp. 121-128, 2011.

[8] J. K. Seo and M. Mahendran, "Plastic bending behaviour and section moment capacities of mono-symmetric LiteSteel beams with web openings," Thin-walled Structures, vol. 49, pp. 513-522, 2011.

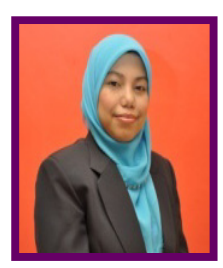

Fadhluhartini Muftah joined the Faculty of Civil Engineering, Universiti Teknologi Mara (UiTM) Pahang, Malaysia in 2008 after graduated at Universiti Teknologi Mara (UiTM) Malaysia. Since coming to UiTM Pahang, she has served on the structural and concrete departments and teaches students about structural analysis and design courses. She completed up the diploma, degree and master at UiTM. Together with Mohd Syahrul Hisyam, Mohd Fakri and Dr Tan Cher Siang, she helped develop and study on cold-formed steel (CFS) structure and CFS composite. She was born 1982 in Johor, Malaysia.

Fig. 6. The dimension of reinforced concrete beam 